\title{
System productivity, profitability and economic efficiency as influenced by various levels and sources of nutrients in sweet corn-potato cropping systems
}

\section{B.S. Gunjal}

Correspondence to :

\section{B. S. Gunjal}

Department of Agronomy, Mahatma Phule Krishi Vidyapeeth, Rahuri, Ahmednagar (M.S.) India Email : bsgunjal3@gmail. com
ABSTRACT : An experiment on effect of integrated nutrient management in sweet corn-potato cropping sequence was conducted during Kharif and Rabi seasons of 2014-15 and 2015-16 at Instructional Research Farm, Central Campus, Post Graduate Institute, Mahatma Phule Krishi Vidyapeeth, Rahuri. The experiment was laid out in a Randomized Block Design with three replications in sweet corn and split plot design in potato crop. The soil of the experimental field was clayey in texture with low in available nitrogen $\left(241.35 \mathrm{~kg} \mathrm{ha}^{-1}\right)$, medium in available phosphorus $\left(22.85 \mathrm{~kg} \mathrm{ha}^{-1}\right)$ and high in potassium $\left(365.75 \mathrm{~kg} \mathrm{ha}^{-1}\right)$, moderately alkaline in reaction $(\mathrm{pH} 8.2)$. The treatments consisted $\mathrm{T}_{1}-100 \% \mathrm{GRDF}, \mathrm{T}_{2}$ $-75 \% \mathrm{RDN}+25 \% \mathrm{~N}$ through FYM, $\mathrm{T}_{3}-75 \% \mathrm{RDN}+25 \% \mathrm{~N}$ through $\mathrm{VC}, \mathrm{T}_{4}-100 \% \mathrm{RDN}+25 \% \mathrm{~N}$ through FYM T $5-100 \% \mathrm{RDN}+25 \% \mathrm{~N}$ through VC, $\mathrm{T}_{6}-125 \% \mathrm{RDN}+25 \% \mathrm{~N}$ through FYM and $\mathrm{T}_{7}-$ $125 \% \mathrm{RDN}+25 \% \mathrm{~N}$ through VC for Kharif sweet corn as a main plot treatment, whereas for Rabi potato two sub plot treatment levels of GRDF viz., $\mathrm{F}_{1}-75 \%$ GRDF and $\mathrm{F}_{2}-100 \%$ GRDF replicated in split plot design resulting in seven treatment combinations replicated thrice during Kharif season and fourteen treatment combinations during Rabi season in RBD-split plot design replicated thrice. The experiment was conducted on same site without changing the randomization of the treatments for successive years. The data in respect of important growth and yield attributes of Kharif sweet corn and Rabi potato were recorded. The sweet corn-potato cropping sequence was also assessed through monetary benefits, micro climate meteorological parameters, nutrient uptake and cumulative nutrient balance sheet of nitrogen, phosphorus and potassium. The most important findings emerged from the present investigation are summarized below. Among the INM treatments, the various fertilizer levels to preceding sweet corn crop significantly influenced $\mathrm{T}_{7}-125 \% \mathrm{RDN}+25 \% \mathrm{~N}$ through $\mathrm{VC}$ was found superior in growth attributes of sweet corn viz., plant height, number of leaves plant ${ }^{-1}$, leaf area and dry matter plant ${ }^{-1}$ at all crop growth stages of sweet corn during both the years of Kharif season. The treatment $\mathrm{T}_{7}-125 \% \mathrm{RDN}+25 \% \mathrm{~N}$ through $\mathrm{VC}$ recorded significantly higher values of all yield contributing characters of sweet corn viz., length of cob with husk $(28.55$ and $29.80 \mathrm{~cm})$, girth of cob with husk (22.36 and $22.97 \mathrm{~cm})$, length of cob without husk $(23.88$ and $24.92 \mathrm{~cm})$, girth of cob without husk (18.82 and $19.87 \mathrm{~cm}$ ), weight of cob plant ${ }^{-1}(308.65$ and $320.26 \mathrm{~g})$, weight of cob without husk $(255.33$ and $256.87 \mathrm{~g}) \mathrm{cob}^{-1}$, weight of husk (53.32 and 63.39 g), weight of grains $\mathrm{cob}^{-1}(203.41$ and $204.82 \mathrm{~g}$ ), number of grain lines $\mathrm{cob}^{-1}\left(18.44\right.$ and 18.65), number of grain lines ${ }^{-1}$ (38.65 and 39.23), number of grains $\operatorname{cob}^{-1}$ (712.71 and 731.64) weight of shelled cob (51.92 and 52.05 g) during both the years of investigation. The maximum and significantly higher green cob yield (275.55 and $281.55 \mathrm{q} \mathrm{ha}^{-}$ 
$\left.{ }^{1}\right)$, green fodder yield (542.83 and $\left.554.19 \mathrm{q} \mathrm{ha}^{-1}\right)$, biological yield $\left(818.38\right.$ and $\left.835.74 \mathrm{q} \mathrm{ha}^{-1}\right)$ and harvest index (33.67 and 33.69\%) of sweet corn was observed in treatment $\mathrm{T}_{7}-125 \% \mathrm{RDN}+25 \% \mathrm{~N}$ through $\mathrm{VC}$ during both the years of Kharif season experiment.The treatment $\mathrm{T}_{7}-125 \% \mathrm{RDN}+25 \% \mathrm{~N}$ through VC recorded significantly higher absorbed photo synthetically active radiation (APAR), photosynthetic rate, stomatal conductance, $\mathrm{CO}_{2}$ concentration and lower values for stomatal resistance and leaf temperature at all the growth stages during both the years. The maximum gross monetary returns (Rs. 343198 , Rs. 367449 and 355324 ha $^{-1}$ ) were obtained by treatment $\mathrm{T}_{7}-125 \% \mathrm{RDN}+25 \% \mathrm{~N}$ through VC, but the maximum net monetary returns (Rs. 266790, Rs. 284944 and Rs. 275867 ha $^{-1}$ ) and B:C ratio (4.67, 4.69 and 4.68 ) were obtained by treatment $\mathrm{T}_{6}-125 \% \mathrm{RDN}+25 \% \mathrm{~N}$ through FYM during both years and pooled mean over years. The quality parameters viz., protein content (12.01 and $11.81 \%)$, starch content (52.86 and 52.97\%) reducing sugar (3.70 and 3.72\%) non- reducing sugar (8.64 and $8.81 \%$ ) and total sugar (12.79 and $12.99 \%$ ) were at starch content (52.86 and $52.97 \%)$ registered by treatment $\mathrm{T}_{7}-125 \% \mathrm{RDN}+25 \% \mathrm{~N}$ through VC during both the years of experimentation. The maximum total uptake of nitrogen (304.57 and $291.73 \mathrm{~kg} \mathrm{ha}^{-1}$ ), phosphorus (32.27 and $33.49 \mathrm{~kg} \mathrm{ha}^{-1}$ ) and potassium (114.98 and $126.56 \mathrm{~kg} \mathrm{ha}^{-1}$ ) by sweet corn was recorded with application of $\mathrm{T}_{7}-125 \% \mathrm{RDN}+25 \% \mathrm{~N}$ through VC during both the years. Among the INM treatments, the various levels to preceding sweet corn crop significantly influenced $\mathrm{T}_{1}-100 \%$ GRDF was found superior in growth attributes of potato viz., plant height, number of leaves plant ${ }^{-1}$, leaf area and dry matter plant ${ }^{-1}$ at all crop growth stages of potato during both the years of experimentation. The various INM fertilizer levels to preceding sweet corn crop significantly influenced $\mathrm{T}_{1}-100 \%$ GRDF was found to be superior in yield attributes of potato viz., medium tubers, big tubers, total tubers, weight of tubers per plant. The various fertilizer levels to preceding sweet corn crop significantly influenced $\mathrm{T}_{1}-100 \%$ GRDF was found to be superior in tuber yield (280.21 and $\left.286.96 \mathrm{q} \mathrm{ha}^{-1}\right)$ and haulm yield (12.31 and $\left.13.52 \mathrm{q} \mathrm{ha}^{-1}\right)$ during both the years of Rabi season experimentation. The various fertilizer levels to preceding sweet corn crop significantly influenced $\mathrm{T}_{1}-100 \%$ GRDF was found superior in total gross monetary returns (Rs. 294786, 330562 and $\left.312674 \mathrm{ha}^{-1}\right)$, total net monetary returns (Rs. 185639, 210831 and $\left.198235 \mathrm{ha}^{-1}\right)$ and B:C ratio (2.70, 2.76 and 2.73 ) during first year, second year and pooled mean over years. The quality parameters viz., protein content $(9.47$ and $9.56 \%)$ and starch content $(70.79$ and $70.88 \%)$ were at higher magnitude registered by treatment $\mathrm{T}_{1}-100 \%$ GRDF during both the years of experimentation. The maximum total uptake of nitrogen (127.02 and $128.90 \mathrm{~kg} \mathrm{ha}^{-1}$ ), phosphorus (20.02 and $20.31 \mathrm{~kg} \mathrm{ha}^{-1}$ ) and potassium ( 151.61 and $153.13 \mathrm{~kg} \mathrm{ha}^{-1}$ ) by potato was recorded with application of $\mathrm{T}_{7}-125 \% \mathrm{RDN}+25 \% \mathrm{~N}$ through $\mathrm{VC}$ during both the years. The economic evaluation of sweet corn -potato cropping sequence was assessed in terms of net monetary returns and B:C ratio over the period of two years. The application of $\mathrm{T}_{6}-125 \% \mathrm{RDN}+25 \% \mathrm{~N}$ through FYM to preceding crop sweet corn during Kharifseason followed by $\mathrm{F}_{1}-75 \%$ GRDF to potato during Rabi season obtained maximum net monetary returns (Rs. 447329, Rs. 490200 and Rs. 468765 ha $\left.^{-1}\right)$ and B:C ratio (3.47, 3.49 and 3.48) during both the years and the pooled mean over the years. The productivity of cropping system in term of sweet corn-equivalent yield (system productivity) was significantly higher in treatment $\mathrm{T}_{1}-100 \% \operatorname{GRDF}(309.71,329.99$ and 319.85 $\left.\mathrm{q} \mathrm{ha}^{-1}\right)$, but the maximum total system productivity yield $\left(576.29,602.92\right.$ and $\left.589.61 \mathrm{q} \mathrm{ha}^{-1}\right)$ were obtained by treatment $\mathrm{T}_{6}-125 \% \mathrm{RDN}+25 \% \mathrm{~N}$ through FYM during both the years and the pooled mean over the years in sweet corn-potato cropping sequence. The maximum production efficiency was obtained by treatment $\mathrm{T}_{1}-100 \% \operatorname{GRDF}\left(172.06,183.33\right.$ and $\left.177.69 \mathrm{~kg} \mathrm{ha}^{-1} \mathrm{day}^{-1}\right)$. But, relative economic efficiency

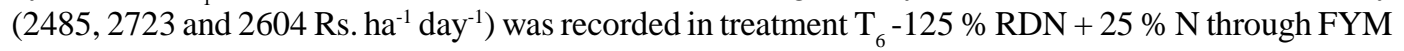
during both the years and the pooled mean over the years. The performance of sweet corn-potato cropping sequence was assessed in terms of residual fertility status at the end of two years crop sequence. The treatment $\mathrm{T}_{1}-100 \%$ GRDF to preceding crop sweet corn during Kharif season registered minimum net loss of nitrogen, phosphorus and maximum gain of potassium as well as improved physico-chemical and biological properties. Based on two years of experiment it could be concluded that, application of treatment $\mathrm{T}_{6}-125 \% \mathrm{RDN}+25 \% \mathrm{~N}$ through FYM and common seed treatment with Azotobacter + PSB to preceding crop sweet corn during Kharifseason followed by $\mathrm{F}_{1}-75 \%$ GRDF to potato during Rabi season to obtain net monetary returns, benefits-cost ratio and maximum resource use efficiency and indicators of energy use efficiency. Application of FYM for the previous crop to get 
Paper History :

Received : 22.05.2019;

Revised : 15.07.2019;

Accepted : 16.08.2019 better yield of next crop in arid and semi-arid regions of Maharashtra.

KEY WORDS : Cropping system, Potato, Profitability, Soil properties, sweet corn, System productivity

How To Cite This PAper : Gunjal, B.S. (2019). System productivity, profitability and economic efficiency as influenced by various levels and sources of nutrients in sweet corn- potato cropping systems. Internat. Res. J. Agric. Eco. \& Stat., 10 (2) : 262-271, DOI : 10.15740/HAS/IRJAES/10.2/262-271. Copyright@ 2019: Hind Agri-Horticultural Society. 